\title{
Utilization of Common Hazelnut (Corylus avellana L.) Prunings for Pulp Production
}

\section{Upotreba biomase nastale orezivanjem stabala običnog lješnjaka (Corylus avellana L.) za proizvodnju celuloze}

\author{
Original scientific paper • Izvorni znanstveni rad \\ Received-prispjelo: 2. 7. 2015. \\ Accepted-prihvaćeno: 5. 5. 2016. \\ UDK: $630 * 861.01 ; 674.031 .632 .1 .14$ \\ doi:10.5552/drind.2016.1529
}

\begin{abstract}
For the purpose of this study, pulp and handseet were produced from common hazelnut (Coryllus avellana L.) wood by using Kraft methods. Chip/solution ratio was chosen as 1/5, cooking temperature was $170^{\circ} \mathrm{C}$ and time for reaching the maximum temperature was 90 minutes. Screened yield was found best in 20/26 active alkali/ sulfidity ratio with $47.59 \%$. With increased active alkali/sulfidity ratios, screened yield was decreased. The best beating degree has been identified as the $50 \mathrm{SR}{ }^{\circ}$. According to cooking parameters, while NaOH/Na2S ratio was 20/26\%, tearing index, breaking length and burst index were reached to the maximum value of $3.83 \mathrm{mN} \cdot \mathrm{m} / \mathrm{g}, 43.23 \mathrm{~N} \cdot \mathrm{m} / \mathrm{g}$ and $1.87 \mathrm{kPa} \cdot \mathrm{m}^{2} / \mathrm{g}$, respectively. These values were used for selecting the optimum cooking parameters.
\end{abstract}

Key words: common hazelnut wood, Kraft pulp production, paper, wood pruning

SAŽETAK • Za potrebe istraživanja kraft metodom proizvedena je celuloza od drva običnog lješnjaka (Coryllus avellana L.). Omjer između iverja i otopine bio je $1: 5$, temperatura kuhanja bila je $170{ }^{\circ} \mathrm{C}$, a vrijeme postizanja maksimalne temperature iznosilo je 90 minuta. Najbolji prinos celuloze dobiven je pri omjeru lužine $i$ sulfida 20 : 26 i iznosio je 47,59\%. S povećanjem omjera lužine i sulfida smanjivao se prinos nakon prosijavanja. Pokazalo se da je najbolji stupanj mljevenja 50 SR ${ }^{\circ}$. Pri različitim parametrima kuhanja i pri omjeru NaOH/Na $\mathrm{S}_{2}$ od $20: 26$ $\%$ indeks cijepanja, duljina lomljenja i indeks pucanja postigli su maksimalne vrijednosti od 3,83 $\mathrm{mN} \cdot \mathrm{m}^{2} / \mathrm{g}, 43,23$ $\mathrm{N} \cdot \mathrm{m} / \mathrm{g}$ i 1,87 $\mathrm{kPa} \cdot \mathrm{m}^{2} / \mathrm{g}$. Te su vrijednosti upotrijebljene za odabir optimalnih parametara kuhanja.

Ključne riječi: drvo običnog lješnjaka, proizvodnja kraft celuloze, papir, drvo od rezidbe

\section{INTRODUCTION \\ 1. UVOD}

Hazelnut (Corylus) from Betulaceae family has natural distribution throughout Balkans, Asia, Iran and northern Turkey, and covers 10 species (Yaltırık and Efe, 2000). Having the highest commercial value in the world, Corylus avellana L. (FAOSTAT, 2011) is the widest species in our country (Sarıbaş, 2012). The total hazelnut farming area in Turkey was 6.678.649 ha in the year 2010 (TMO, 2013). Corylus avellana L. is the most important among them from the commercial aspect (FAOSTAT, 2011).

The yield of hazelnut is higher in north and east exposures in eastern Black Sea region at altitudes of 250-1000 m, and it has natural distribution at altitudes

\footnotetext{
Authors are assistant professors at Bartin University, Faculty of Forestry, Department of Forest Industrial Engineering, Bartin, Turkey.

${ }^{1}$ Autori su docenti Sveučilišta u Bartinu, Šumarski fakultet, Odjel za industrijsku preradu drva, Bartin, Turska.
} 
of 0-2500 m (Aydınoğlu, 2012). Although almost $70 \%$ of the world's hazelnut production is provided by Turkey (TMO, 2013), the hazelnut wood could not have industrial use in our country. When cutting old trees with decreased yield, most of them are burnt. Some of their parts are used in traditional handworks such as production of wicker chairs, baskets, and barrel rings (TEMA 2004). However, since the interest in these handcrafts has decreased and not all of pruning residuals are suitable for use in these areas, the hazelnut wood cannot be utilized properly.

In a study, González et al. (2011) showed that the prunings from orange trees can be used to obtain soda pulp of acceptable quality with yields from 34.10 to $51.81 \%$. In another study, Gencer (2015) studied the utilization of kiwi pruning waste for kraft paper production and the effect of the bark on paper properties. According to the results, pulp making should then be decided based on an economic analysis. Pruning waste obtained from the kiwi plant is a sustainable fiber source since the plants are pruned annually. This waste should be utilized in the pulp and paper industry in order to provide income for growers.

In this study, in order to have preliminary information about the usability of hazelnut wood in pulp production, morphological properties and chemical components of the wood have been determined. Based on these properties, it can be concluded whether it is suitable for pulp production. In pulp production, the Kraft method was preferred. Kraft method was selected for its shorter cooking duration, high-resistance of its pulp, and the fact that it is suitable for all wood species (Casey, 1980). When applying the Kraft method, 6 times of cooking were performed in order to determine $\mathrm{Na}_{2} \mathrm{~S}$ and $\mathrm{NaOH}$ ratios,. While producing paper from any pulp, many of the paper characteristics are determined by beating. In other words, paper is produced in a beater. For this reason, in order to determine the characteristics that the paper will gain at different beating degrees, the most appropriate beating level was determined in our study by producing paper from unbeaten pulp and pulps beaten at beating degrees of $(18 \pm 2), 35$ and $50 \mathrm{SR}^{\circ}$.

The aim of this study was to investigate the possibility of use of the hazelnut wood residues, not used industrially for any products, in the pulping and paper industry, and also to determine the anatomical and chemical properties of the hazelnut wood.

\section{MATERIALS AND METHODS}

\section{MATERIJALI I METODE}

The common hazelnut (Corylus avellana L.) wood used in this study was obtained from north-west exposure at 35-60 $\mathrm{m}$ altitude at coordinates of $41^{\circ} 36^{\prime}$ $\mathrm{N}, 32^{\circ} 19^{\prime} \mathrm{E}$. After being cut into $5 \mathrm{~cm}$ parts in longitudinal direction, shredding process was executed manually. The branches and the other parts of the tree were also used in this study. $\mathrm{NaOH}$ and $\mathrm{Na}_{2} \mathrm{~S}$ used in pulp production were obtained from MERCK Darmstadt, Germany. Wood samples were macerated by chloride method (Wise and Jahn, 1952), and the preparations were evaluated from the aspect of their fiber lengths by their measurement.

Elasticity ratio $=($ Lumen diameter $\times 100) /$ Fiber width . Runkel ratio $=($ Fiber sheath thickness $\mathrm{x} 2) /$ Lumen diameter

Felting ratio $=$ Fiber length $/$ Fiber width

Solidity coefficient $=($ Fiber wall thickness $\mathrm{x} 100) /$ Fiber width

Holocellulose was determined by Wise's chloride method (Wise and Jahn, 1952), and alpha cellulose (Rowell, 2005), lignin (TAPPI T 222 om-02), ash (ASTM D 1102-84), solubility in alcohol (TAPPI T $204 \mathrm{~cm}-97$ ) and solubility in cold- and hot-water (TAPPI T $207 \mathrm{~cm}-99)$ were also determined. Chip/solution ratio $(1 / 5)$, time for reaching maximum temperature (90 min.) and duration of cooking at maximum temperature (60 min.) were taken as constant for pulping. In determining the cooking temperature, kraft cooking temperature $\left(170{ }^{\circ} \mathrm{C}\right)$, which was accepted to be ideal by İstek and Özkan (2006), was taken as constant. $\mathrm{NaOH}(\%)-\mathrm{Na}_{2} \mathrm{~S}(\%)$ ratios were taken as $18-28,20$ 26, 22-24, 24-22, 26-20 and 28-18, and six different cooking procedures were executed. Kappa number of pulps was determined according to TAPPI T 236 om99, while viscosity of pulp was determined according to SCAN-CM 15-62 standards. 13 replicates were produced in accordance with different beating conditions. In all papers dealing with beating at $\left(18 \pm 2^{\circ} \mathrm{SR}^{\circ}\right), 35 \pm 2^{\circ}$ $\mathrm{SR}^{\circ}$ and $50 \pm 2^{\circ} \mathrm{SR}^{\circ}$, opacity and brightness, tearing index, break index, and burst index values were determined in accordance with TAPPI T 519 om-02, TAPPI T 525 om-02, TAPPI T 414 om-98, TAPPI T 494 om-01 and TAPPI T 403 om-02 standards, respectively. SPSS 16.0 package software was used for assessment of data.

According to Gençer and Şahin (2015), the highest values of breaking length, brightness, burst index, tearing index, opacity and whiteness were taken into account, as well as the values at which the difference between those values was not statistically significant at $5 \%$, and a scoring table (Tab. 5) was developed in order to determine the optimum conditions. Moreover, the highest values and the value(s) at which the difference between those values was not statistically significant at $5 \%$ were each graded as 1 , while all of the remaining values were graded as 0 .

\section{RESULTS AND DISCUSSION 3. REZULTATI I RASPRAVA}

When loading chips into cooking boiler for pulping production, the higher the oven-dry density value of the wood, the higher is the yield obtained from the unit volume of that chip. Therefore, the boiler capacity changes proportionally to the density of wood species. The high density of the hazelnut wood has an important advantage compared to species of wood with low density. Oven-dry density of Corylus avellana L. wood was determined to be $0.67 \mathrm{~g} / \mathrm{cm}^{3}$., This value of Corylus colurna from the same family, grown in our country, is $0.699 \mathrm{~g} / \mathrm{cm}^{3}$ (Korkut et al., 2008), while that of Corylus colurna L. grown in the Czech Republic is 
Table 1 Comparison of fiber lengths with Corylus avellana L. wood

Tablica 1. Usporedba duljine vlakanaca različitih vrsta drva i drva lješnjaka (Corylus avellana L.)

\begin{tabular}{|l|c|c|c|c|}
\hline $\begin{array}{l}\text { Wood species } \\
\text { Vrsta drva }\end{array}$ & $\begin{array}{c}\text { Fiber length } \\
\text { Duljina vlakanaca } \\
\mathrm{mm}\end{array}$ & $\begin{array}{c}\text { Fiber width } \\
\text { Sirina vlakanaca } \\
\mu \mathrm{m}\end{array}$ & $\begin{array}{c}\text { Lumen width } \\
\text { Sirina pore } \\
\mu \mathrm{m}\end{array}$ & $\begin{array}{c}\text { Wall thickness } \\
\text { Debljina stijenke } \\
\mu \mathrm{m}\end{array}$ \\
\hline Corylus avellana L.(1) & 1.04 & 22.2 & 13.66 & 4.3 \\
\hline Corylus avellana L.(2) & 1.06 & 23.8 & 14.08 & 4.8 \\
\hline Betula verrucosa (3) & 1.10 & 20.0 & - & 1.9 \\
\hline Eucalyptus globus (3) & 1.00 & 13.0 & - & 1.6 \\
\hline Fagus silvatica var. purpurea (3) & 1.03 & 19.0 & - & 7.5 \\
\hline Qercus robur (3) & 1.10 & 21.0 & - & 6.0 \\
\hline Fraxinus excelsior (3) & 1.05 & 16.0 & - & 3.8 \\
\hline
\end{tabular}

Key/Legenda: 1 - authors' finding, 2 - Merev, 1998, 3 - Rydholm, 1965

$0.627 \mathrm{~g} / \mathrm{cm}^{3}$ (Zeidler, 2012). The fiber morphology of the raw material plays a decisive role for the characteristics of the paper to be produced. For this reason, Table 1 presents morphological characteristics of some important hardwood trees from literature compared with fiber lengths of Corylus avellana L. wood.

According to IAWA (1989), the trees with mean fiber lengths between 900 and $1600 \mu \mathrm{m}$ are considered as "medium length" fiber group. As can be seen in Tab. 2 , it was determined that Corylus avellana L. wood is in this group with its $1.04 \mathrm{~mm}$ fiber length. Merev (1998) has determined the fiber length, fiber width, lumen wi$\mathrm{dth}$, wall thickness, and trahe length of Corylus avellana L. wood to be $1.05 \mathrm{~mm}, 23.76 \mu \mathrm{m}, 14.08 \mu \mathrm{m}, 4.80 \mu \mathrm{m}$, and $599.98 \mu \mathrm{m}$, respectively. Merev's determinations show similarities with the values obtained in our study. They are the same as Taxus brevifolia and Quercus stellate, and have similarities with Carya cordiformis and Ulmus alata (0.66 g/ $\left.\mathrm{cm}^{3}\right)$ (Miles and Smith, 2009).

Elasticity coefficient, rigidity coefficient, Runkel ratio, and felting ratio of hazelnut wood are 61.53, 19.23, 0.63 , and 46.90 , respectively, and these values show similarity with those of kiwi (Yaman and Gençer, 2005) calculated to be $61.99,19.00,0.61$, and 44.03 . When the relationship between specific weight and fiber lengths of hazelnut wood was examined, it could be seen that elasticity coefficient was 61.53 and specific weight was 0.67 $\mathrm{g} / \mathrm{cm}^{3}$. The woods with elasticity coefficient of 50-75 and weight of $0.55-0.70 \mathrm{~g} / \mathrm{cm}^{3}$ are classified into this group. The woods in this group provide papers with good resistance characteristics, because they are partly grinded since their lumen gaps are wide although wall thicknesses are a little bit high (Bostanc1, 1987). With such characteristics, Corylus avellana L. is classified into elastic fiber class, and it has advantages in paper production compared to species having fibers with thick and thin wall. Since thick-walled cells do not collapse, the potential contact area decreases. Consequently, the burst resistance depending on fiber connection also decreases. On the other hand, since the individual fiber strength of thin-walled fibers is low, their tearing resistance is also low (Panshin and de Zeeuw, 1970).

The rigidity coefficient has been found to be 19.23. The physical resistance characteristics of papers made of fibers having high rigidity coefficients are affected negatively and not enough inter-fiber connection can be established (Yaman and Gençer, 2005). High rigidity coefficient means low physical resistance qualifications, especially the low level of burst and breaking resistances. Runkel ratio has been calculated to be 0.63. If the Runkel ratio is less than 1 , it is classified into thin-walled fiber class. Except the tearing and folding resistance, all of the characteristics of paper made of these fibers show improvement. Felting ratio has been found to be 46.93. Although the fibrous raw materials having felting ratio less than 70 are considered to be invaluable in terms of paper production, since it has been revealed that the physical characteristics of pulps obtained from the fibers of hardwoods having felting ratio less than 70 are good, it can be stated that this ratio does not indicate a systematical relationship with various physical characteristics of paper but indicates the relationship only with tearing resistance of the paper (Bostanc1, 1987). According to these results, hazelnut wood can compete with forest trees having significant place in pulp production (Table 1) from the morphological aspect. Corylus avellana L. and Corylus colurna L. are two important hazelnut species in Turkey. Some physical and chemical characteristics of these wood species are presented in Tab. 2.

Table 2 Some physical and chemical characteristics of Corylus avellana L. and Corylus colurna L. woods Tablica 2. Neka fizikalna i kemijska svojstva drva Corylus avellana L. i Corylus colurna L.

\begin{tabular}{|l|c|c|}
\hline $\begin{array}{l}\text { Characteristics } \\
\text { Obilježje }\end{array}$ & $\begin{array}{c}\text { Corylus avellana } \mathbf{L} . \\
\text { (Findings) }\end{array}$ & $\begin{array}{c}\text { Corylus colurna } \mathbf{L} . \\
\text { (Korkut } \text { et al., 2009) }\end{array}$ \\
\hline Extractive matter, \% / ekstraktivne tvari, \% & 2.83 & 7.42 \\
\hline Cold-water solubility, \% / topljivost u hladnoj vodi, \% & 2.90 & 6.30 \\
\hline Hot-water solubility, \% / topljivost u toploj vodi, \% & 3.70 & 7.40 \\
\hline Holocellulose, \% / holoceluloza, \% & 82.07 & 68.80 \\
\hline$\alpha$-cellulose, \% / -celuloza, \% & 41.33 & 43.50 \\
\hline Lignin, \% / lignin, \% & 15.89 & 23.60 \\
\hline 1 NaOH solubility, \% / topljivost u lužini, \% & 18.48 & 25.50 \\
\hline Ash content, \% / sadržaj pepela, \% & 0.72 & 0.30 \\
\hline
\end{tabular}


Table 3 Screened yield, screenings, total yield, Kappa number, and viscosity of pulps obtained from Corylus avellana L. wood

Tablica 3. Prinos prosijavanja, prosijavanje, ukupni prinos, Kappa broj i viskozitet celuloze proizvedene od drva Corylus avellana $\mathrm{L}$.

\begin{tabular}{|l|c|c|c|c|c|}
\hline $\begin{array}{c}\text { NaOH-Na } \\
\%\end{array}$ & $\begin{array}{c}\text { Screened yield } \\
\text { Prinos prosijavanja } \\
\%\end{array}$ & $\begin{array}{c}\text { Reject } \\
\text { Skart } \\
\%\end{array}$ & $\begin{array}{c}\text { Total yield } \\
\text { Ukupni prinos } \\
\%\end{array}$ & $\begin{array}{c}\text { Kappa number } \\
\text { Kappa broj }\end{array}$ & $\begin{array}{c}\text { Viscosity } \\
\text { Viskozitet } \\
\mathrm{cm}^{3} / \mathrm{g}\end{array}$ \\
\hline $\mathrm{K} 1 / 18-28$ & 45.72 & 0.20 & 45.92 & 17.25 & 778.26 \\
\hline $\mathrm{K} 2 / 20-26$ & 47.60 & 0.05 & 47.64 & 17.35 & 947.01 \\
\hline $\mathrm{K} 3 / 22-24$ & 45.06 & 0.13 & 45.19 & 15.25 & 697.17 \\
\hline $\mathrm{K} 4 / 24-22$ & 43.55 & 0.07 & 43.62 & 14.65 & 685.47 \\
\hline $\mathrm{K} 5 / 26-20$ & 40.67 & 0.06 & 40.73 & 14.55 & 680.39 \\
\hline $\mathrm{K} 6 / 28-18$ & 38.21 & 0.06 & 38.27 & 14.45 & 607.48 \\
\hline
\end{tabular}

$\mathrm{K}$ - Kraft pulping / priprema kraft pulpe

When physical and chemical properties of Corylus avellana L. wood, presented in Table 2, are compared with those of Corylus colurna L. wood, it can be concluded that solubility values, $\alpha$-cellulose, and lignin contents are low in Corylus colurna L. wood, while holocellulose and ash content values are high in Corylus avellana L. wood .

\subsection{The effect of active alkali/sulfidity ratio on pulp yield}

3.1. Utjecaj omjera lužine i sulfida na prinos celuloze

Some characteristics of Kraft pulp obtained from Corylus avellana L. wood, such as screened yield, total yield, Kappa number, and viscosity, are presented in Table 3.

When producing paper from pulp, many characteristics of the paper depend on the beating degree.
Beating mainly affects the physical characteristics. With beating, primary fiber wall is shivered, fiber length decreases, elasticity increases, and outer specific area of fiber increases. As the duration of beating increases, the breaking and burst indices increase, tearing index of paper sheets increases rapidly and then these properties decrease. Opacity and brightness of paper sheets decrease. Similar results are generally determined due to beating (Gencer and Sahin, 2015).

When examining Table 4, it can be seen that the same letters in the same columns indicate that the differences are statistically non-significant at confidence level of $95 \%$. When examining the effect of different active alkali/sulfidity ratios on opacity, it can be seen that the highest opacity in papers produced from non-beaten pulps has been measured to be $99.93 \%$ at active alkali/

Table 4 Some physical, optical, and mechanic characteristics of sample papers obtained from Corylus avellana L. wood and Duncan test

Tablica 4. Određena fizikalna, optička i mehanička svojstva uzoraka papira proizvedenih od drva Corylus avellana L. i rezultati Duncanova testa

\begin{tabular}{|c|c|c|c|c|c|c|}
\hline \multirow[b]{2}{*}{$\mathbf{S R}^{\circ}$} & \multirow[b]{2}{*}{ No } & \multicolumn{2}{|c|}{$\begin{array}{c}\text { Optical characteristics } \\
\text { Optička svojstva }\end{array}$} & \multicolumn{3}{|c|}{$\begin{array}{l}\text { Mechanic characteristics } \\
\text { Mehanička svojstva }\end{array}$} \\
\hline & & $\begin{array}{c}\text { Opacity } \\
\text { Neprozirnost } \\
\% \\
\end{array}$ & $\begin{array}{c}\text { Brightness } \\
\text { Sjajnost } \\
\%\end{array}$ & $\begin{array}{c}\text { Tearing index } \\
\text { Indeks cijepanja } \\
\mathrm{mN} \cdot \mathrm{m}^{2} / \mathrm{g}\end{array}$ & $\begin{array}{c}\text { Breaking index } \\
\text { Indeks lomljivosti } \\
\mathrm{N} \cdot \mathrm{m} / \mathrm{g}\end{array}$ & $\begin{array}{c}\text { Burst index } \\
\text { Indeks pucanja } \\
\mathrm{kPa} \cdot \mathrm{m}^{2} / \mathrm{g}\end{array}$ \\
\hline \multirow{6}{*}{$18 \pm 2$} & K1 & $99.88 \mathrm{G}$ & $25.18 \mathrm{H}$ & $2.93 \mathrm{BCD}$ & $34.86 \mathrm{C}$ & $1.51 \mathrm{D}$ \\
\hline & $\mathrm{K} 2$ & $99.89 \mathrm{G}$ & $25.39 \mathrm{I}$ & $3.83 \mathrm{I}$ & $43.23 \mathrm{D}$ & $1.87 \mathrm{E}$ \\
\hline & K3 & $99.92 \mathrm{G}$ & $26.05 \mathrm{~K}$ & $2.64 \mathrm{ABC}$ & $34.69 \mathrm{C}$ & $1.30 \mathrm{C}$ \\
\hline & K4 & $99.93 \mathrm{G}$ & $26.99 \mathrm{M}$ & $2.60 \mathrm{AB}$ & $29.71 \mathrm{~B}$ & $1.37 \mathrm{C}$ \\
\hline & K5 & $99.85 \mathrm{~F} \mathrm{G}$ & $29.38 \mathrm{O}$ & $2.41 \mathrm{~A}$ & $29.57 \mathrm{~B}$ & $1.11 \mathrm{~B}$ \\
\hline & K6 & $99.79 \mathrm{~F} \mathrm{G}$ & $32.17 \mathrm{P}$ & $2.34 \mathrm{~A}$ & $24.41 \mathrm{~A}$ & $0.95 \mathrm{~A}$ \\
\hline \multirow{6}{*}{$35 \pm 2$} & K1 & $99.21 \mathrm{C}$ & $19.50 \mathrm{C}$ & $3.86 \mathrm{I}$ & $80.66 \mathrm{I}$ & $4.62 \mathrm{~K}$ \\
\hline & K2 & $98.44 \mathrm{~B}$ & $19.33 \mathrm{C}$ & $3.63 \mathrm{GHI}$ & $83.29 \mathrm{I}$ & $5.01 \mathrm{~L}$ \\
\hline & K3 & $99.70 \mathrm{EF}$ & $21.69 \mathrm{~F}$ & $3.70 \mathrm{HI}$ & $76.91 \mathrm{H}$ & $4.04 \mathrm{I}$ \\
\hline & K4 & $99.69 \mathrm{EF}$ & $20,19 \mathrm{G}$ & 3.61 FGHI & $70.03 \mathrm{~F}$ & $3.80 \mathrm{H}$ \\
\hline & K5 & $99.69 \mathrm{EF}$ & $25.67 \mathrm{~J}$ & 3.49 FGHI & $69.36 \mathrm{~F}$ & $3.41 \mathrm{G}$ \\
\hline & K6 & $99.59 \mathrm{E}$ & $28.68 \mathrm{~N}$ & $3.43 \mathrm{FGH}$ & $62.61 \mathrm{E}$ & $3.33 \mathrm{FG}$ \\
\hline \multirow{6}{*}{$50 \pm 2$} & K1 & $98.51 \mathrm{~B}$ & $17.75 \mathrm{~A}$ & $3.39 \mathrm{FGH}$ & $86.29 \mathrm{~J}$ & $4.63 \mathrm{~K}$ \\
\hline & K2 & $97.87 \mathrm{~A}$ & $18.26 \mathrm{~B}$ & $3.34 \mathrm{EFGH}$ & $87.86 \mathrm{~J}$ & $5.19 \mathrm{M}$ \\
\hline & K3 & $99.37 \mathrm{D}$ & $20.07 \mathrm{D}$ & 3.26 DEFG & $81.16 \mathrm{I}$ & $4.16 \mathrm{~J}$ \\
\hline & K4 & $99.41 \mathrm{D}$ & $21.23 \mathrm{E}$ & $3.23 \mathrm{DEF}$ & $73.78 \mathrm{G}$ & $3.81 \mathrm{H}$ \\
\hline & K5 & $99.38 \mathrm{D}$ & $23.19 \mathrm{G}$ & $2.99 \mathrm{CDE}$ & $67.52 \mathrm{~F}$ & $3.43 \mathrm{G}$ \\
\hline & K6 & $99.16 \mathrm{C}$ & $26.31 \mathrm{~L}$ & $2.89 \mathrm{BCD}$ & $62.12 \mathrm{E}$ & $3.25 \mathrm{~F}$ \\
\hline
\end{tabular}

After one-way analysis of variance (ANOVA), the Duncan test was used to determine the difference between groups. Important differences between groups were marked by the letter A, B, C..., etc. The letter means the difference between the groups. / Nakon jednosmjerne analize varijance (ANOVA) primijenjen je Duncanov test kako bi se odredile razlike između skupina podataka. Značajne razlike među skupinama prikazane su slovima A, B, C itd. Različita slova označuju značajne razlike među skupinama. 
........ Gençer, Özgül: Utilization of Common Hazelnut (Corylus avellana L.) Prunings...

Table 5 Scoring the optimum pulp production conditions and beating degree

Tablica 5. Bodovanje optimalnih uvjeta proizvodnje celuloze i stupnja mljevenja

\begin{tabular}{|l|c|c|c|c|c|c|}
\hline Properties / Svojstvo & $\begin{array}{c}\mathbf{K} 1 \\
\mathbf{x} / \mathbf{y} / \mathbf{z}\end{array}$ & $\begin{array}{c}\mathbf{K 2} \\
\mathbf{x} / \mathbf{y} / \mathbf{z}\end{array}$ & $\begin{array}{c}\mathbf{K 3} \\
\mathbf{x} / \mathbf{y} / \mathbf{z}\end{array}$ & $\begin{array}{c}\mathbf{K} 4 \\
\mathbf{x} / \mathbf{y} / \mathbf{z}\end{array}$ & $\begin{array}{c}\mathbf{K 5} \\
\mathbf{x} / \mathbf{y} / \mathbf{z}\end{array}$ & $\begin{array}{c}\mathbf{K 6} \\
\mathbf{x} / \mathbf{y} / \mathbf{z}\end{array}$ \\
\hline Opacity / neprozirnost & $1 / 0 / 0$ & $0 / 0 / 1$ & $1 / 1 / 1$ & $1 / 1 / 1$ & $1 / 1 / 1$ & $0 / 1 / 1$ \\
\hline Brightness / sjajnost & $0 / 0 / 0$ & $0 / 0 / 0$ & $0 / 0 / 0$ & $0 / 0 / 0$ & $0 / 0 / 1$ & $1 / 1 / 1$ \\
\hline Tear index / indeks cijepanja & $1 / 1 / 0$ & $1 / 1 / 1$ & $0 / 1 / 0$ & $0 / 1 / 0$ & $0 / 1 / 0$ & $0 / 1 / 0$ \\
\hline Breaking index / indeks lomljivosti & $0 / 1 / 0$ & $1 / 1 / 1$ & $0 / 0 / 0$ & $0 / 0 / 0$ & $0 / 0 / 0$ & $0 / 0 / 1$ \\
\hline Burst index / indeks pucanja & $0 / 0 / 0$ & $1 / 1 / 1$ & $0 / 0 / 0$ & $0 / 0 / 0$ & $0 / 0 / 0$ & $0 / 0 / 0$ \\
\hline Pulp yield / prinos celuloze & $0 / 0 / 0$ & $1 / 1 / 1$ & $0 / 0 / 0$ & $0 / 0 / 0$ & $0 / 0 / 0$ & $0 / 0 / 0$ \\
\hline Kappa number / Kappa broj & $0 / 0 / 0$ & $0 / 0 / 0$ & $0 / 0 / 0$ & $0 / 0 / 0$ & $0 / 0 / 0$ & $1 / 1 / 1$ \\
\hline Viscosity / viskozitet & $0 / 0 / 0$ & $1 / 1 / 1$ & $0 / 0 / 0$ & $0 / 0 / 0$ & $0 / 0 / 0$ & $0 / 0 / 0$ \\
\hline Total point x/y/z / ukupan broj bodova x/y/z & $2 / 2 / 0$ & $5 / 5 / 6$ & $1 / 2 / 1$ & $1 / 1 / 1$ & $1 / 2 / 2$ & $2 / 4 / 4$ \\
\hline
\end{tabular}

$\mathrm{x}-18 \pm 2 \mathrm{SR}^{\circ}, \mathrm{y}-35 \pm 2 \mathrm{SR}^{\circ}, \mathrm{z}-50 \pm 2 \mathrm{SR}^{\circ}$

sulfidity ratio of $24 / 22$. It can be seen that opacity of paper sheets decreased in all samples as the beating duration was increased. When examining the effect of different active alkali/sulfidity ratios on brightness in nonbeaten pulps, it can be concluded that the highest brightness value was $32.17 \%$ at active alkali/sulfidity ratio of 28/18. This value was decreased in all of the samples as the duration of beating was increased.

When examining the effect of different active alkali/sulfidity ratios on tearing index, it can be seen that the tearing index of paper sheets obtained from different active alkali/sulfidity ratio of $20 / 26$ was 3.83 $\mathrm{mN} \cdot \mathrm{m}^{2} / \mathrm{g}$ for non-beaten pulp and $3.86 \mathrm{mN} \cdot \mathrm{m}^{2} / \mathrm{g}$ for pulp beaten at $35 \mathrm{SR}^{\circ}$. As the duration of beating increased, this value also increased in all samples initially, and then it decreased in all of them at $50 \mathrm{SR}^{\circ}$. Breaking index value at active alkali/sulfidity level of 20/26 has peaked in non-beaten pulp and pulps beaten at $35 \mathrm{SR}^{\circ}$ and $50 \mathrm{SR}^{\circ}$, and it increased with beating. It was found to be $43.23,80.66 \mathrm{~N} \cdot \mathrm{m} / \mathrm{g}$ and $87.86 \mathrm{~N} \cdot \mathrm{m} / \mathrm{g}$, respectively. When evaluating the effects of different active alkali/sulfidity ratios and beating on burst index, it can be seen that, with 20/26 active alkali/sulfidity ratio, the sample papers made of unbeaten pulp and pulp beaten at $35 \mathrm{SR}^{\circ}$ and $50 \mathrm{SR}^{\circ}$ had the highest values, and namely $1.87,5.01$ and $5.19 \mathrm{kPa} \cdot \mathrm{m}^{2} / \mathrm{g}$, respectively. Burst and tearing index values obtained from Corylus avella$n a \mathrm{~L}$. wood at similar Kappa number and $\mathrm{SR}^{\circ}$ levels are higher than those obtained from papers made of Olea europaea wood (Requejo et al., 2012).

According to Tab. 5, the most ideal beating conditions were determined by giving 1 point to the best value and to the values having statistically non-significant difference from the best value at confidence level of $95 \%$. When interpreting the columns of Table 4 , all 3 freeness or schopper degrees were taken into consideration. However, while scoring in Table 4, by evaluating each beating value at $18 \pm 2 \mathrm{SR}^{\circ}, 35 \mathrm{SR}^{\circ}$ and 50 $\mathrm{SR}^{\circ}$ beating levels, $x, y$ and $z$ columns were created. This was done with the aim of determining the best beating degree.

When evaluating the pulp, high yield and viscosity values and low Kappa number are desired. The aim of the assessment was to determine the highest yield and viscosity and the lowest Kappa number. Since these values are the properties related to pulp, they are the same for every beating degree. Table 5 presents the scoring used to determine the optimum conditions.

According to Tab. 5, the paper made of K2 pulp gained the highest scores at every beating degree, and peaked when beaten up to $50 \mathrm{SR}^{\circ}$ degrees. According to these results, the cooking conditions of common hazelnut wood can be considered as 20/26 active alkali/ sulfidity, cooking temperature of $170^{\circ} \mathrm{C}, 1 / 5 \mathrm{chip} / \mathrm{solu}$ tion ratio, $90 \mathrm{~min}$. for reaching the maximum temperature, $60 \mathrm{~min}$. of cooking at the highest temperature, and beating degree of $50 \mathrm{SR}^{\circ}$. In our study, pulp has been produced from Common Hazelnut (Corylus avellana L.) wood by Kraft method, and the best beating degree has been determined. However, in order to achieve an exact judgment, we believe that other pulp production methods should also be investigated.

\section{CONCLUSION \\ 4. ZAKLJUČAK}

The fibers of the Hazelnut wood presented in Tab. 1 were determined to be similar to the fibers of the hardwoods commonly used in the wood products industry. Therefore, it can be said that the paper produced from hazelnut wood can be an alternative to commonly used hardwood species. Hazelnut wood has a high $\alpha$-cellulose ratio and a low lignin ratio, hence it can easily be used in an alternative pulping process.

\section{Acknowledgements - Zahvala}

This study has been financially supported by the Scientific Research Center of Bartın University within the scope of the project. We thank the management of Bartın University for their full support throughout the project No: 2013.1.87.

\section{REFERENCES}

\section{LITERATURA}

1. Bostanc1, Ş., 1987: Kâğıt Hamuru Üretimi ve Ağartma Teknolojisi. Karadeniz University, Faculty of Forestry, Karadeniz University Press, General Publication Nr. 114, Faculty Publication Nr. 13, Trabzon.

2. Casey, J. P., 1980: Pulp and Paper Chemistry and Chemical Technology, Vol. 1, Third Edition. Wiley Interscience Publisher Inc., New York, 409. 
3. Gençer, A., 2015: The utilization of kiwi (Actinidia deliciosa) Pruning waste for kraft paper production and the effect of the bark on paper Properties. Drewno, 58 (194): 103-113.

http://dx.doi.org/10.12841/wood.1644-3985.084.08.

4. Gençer, A.; Şahin, M., 2015: Identifying the conditions required for the $\mathrm{NaOH}$ method for producing pulp and paper from sorghum grown in Turkey. BioResources, 10 (2): $2850-2858$.

http://dx.doi.org/10.15376/biores.10.2.2850-2858.

5. Gonzáles, Z.; Rosal, A.; Requejo, A.; Rodríguez, A., 2011: Production of pulp and energy using orange tree prunings. Bioresource Technology, 102 (19): 9330-9334. http://dx.doi.org/10.1016/j.biortech.2011.07.088.

6. Korkut, D. S.; Korkut, S.; Bekar, I.; Budakçı, M.; Dilik, T.; Çakıcıer, N., 2008: The effects of heat treatment on the physical properties and surface roughness of Turkish hazel (Corylus colurna L.) wood. International Journal of Molecular Sciences, 9: 1772-1783. http://dx.doi.org/10.3390/ijms9091772.

7. Merev, N., 1998: Odun Anatomisi Cilt 1. Doğu Karadeniz Bölgesindeki Doğal Angiospermae Taksonlarının Odun Anatomisi, General Publication Nr. 189, Faculty Publication Nr. 27, Karadeniz Technical University Press, Trabzon.

8. Miles, P. D.; Smith, W. B., 2009: Specific gravity and other properties of wood and bark for 156 tree species found in North America. Res. Note NRS-38. Newtown Square, PA: U.S. Department of Agriculture, Forest Service, Northem Research Station. 35 p.

9. Panshin, A. J.; deZeeuw, C., 1970: Textbook of Wood Technoology, $3^{\text {rd }}$ ed. New York: McGraw-Hill; 705 p., Vol. 1.

10. Requejo, A.; Rodriguez, A.; Colodette, J. L.; Gomide, J. L.; Jimenez, L., 2012: Optimization of ECF bleaching and refining of kraft pulping from olive tree pruning. Bioresources, 7 (3): 4046-4055.

11. Rowell, R. M., 2005: Wood Chemistry and Wood Composites. CRC press, USA.

12. Rydholm, S. A., 1965: Pulping processes. Vol. 1, 1st Ed., Interscience Publishers, California, $1269 \mathrm{p}$.

13. Sarıbaş, M., 2012: Dendroloji II Angiospermae. Kapalı Tohumlular Angiospermae (Amentifeare), Bartın University Publication Nr. 7, Faculty of Forestry Publication Nr. 5, Bartın.

14. TEMA 2004: Ağaçlar, Doğa Severler İçin Rehber Kitap, Marmara Bölgesi Doğal-Egzotik Ağaç ve Çalıları. 3. ed.,
TEMA Foundation Press, Pub. Nr. 39, Turkish Foundation of Foresting, Protecting Natural Assets and Struggle with Erosion, İstanbul.

15. TEPGE 2011: Durum ve Tahmin Findik 2011/2012. TEPGE Yayın No. 1918, ISBN: 978-975-407-338-6, ISSN: 1306-0260. Agricultural Economy and Policy Development Institute, Ankara.

16. TMO 2013: Hazelnut Industry Report of Year 2012. General Directorate of Turkish Grain Board, Ankara.

17. Ververis, C.; Georghiou, K.; Christodoulakis, N.; Santas, P.; Santas, R., 2004: Fiber dimensions, lignin and cellulose content of various plant materials and their suitability for paper production. Industrial Crops and Products, 19 (2004): 245-254. http://dx.doi.org/10.1016/j.indcrop.2003.10.006.

18. Wise, L. E.; Jahn, E. C., 1952: Wood Chemistry. $2^{\text {nd }}$ ed., Vol 1-2. Reinhold Publication Co. New York, U.S.A, 1330.

19. Yaltırık, F.; Efe, A., 2000: Dendrology Handbook, Gymnospermae-Angiospermea. Faculty of Forestry Publication, Istanbul University Publication, Istanbul, Turkey.

20. Yaman, B.; ve Gençer, A., 2005: Trabzon koşullarında yetiştirilen kiwi (Actinidia deliciosa (A. Chev.) C. F. Liang \& A. R. Ferguson) nin morfolojisi. Süleyman Demirel University, Journal of Faculty of Forestry, A (2): 149155 .

21. Zeidler, A., 2012: Variation of wood density in Turkish hazel (Corylus colurna L.) Grown in the Czech Republic. Journal of Forest Science, 58 (4): 145-151.

22. *** 2011: FAOSTAT. http:/faostat.fao.org/site/567 DesktopDefauH.aspx ?PageID $=567$

23. *** 1989: IAWA list of microscopic features for hardwood identification IAWA Bulletin n.s., 10: 219-332.

\section{Corresponding address:}

Assist. Prof. AYHAN GENÇER, Ph.D.

Bartin University

Faculty of Forestry, Forest Industrial Engineering 74100, Bartin, TURKEY

e-mail: ayhangencer61@hotmail.com 